九州大学学術情報リポジトリ

Kyushu University Institutional Repository

\title{
Flood Hazard Assessment of Residential Areas Inside the Van Coc Lake, Hanoi, in an Emergency Situation
}

\section{ANH, Sai Hong}

Laboratory of Water Environment Engineering, Course of Bioproduction Environmental Sciences, Department of Agro-environmental Sciences, Graduate School of Bioresource and Bioenvironmental Sciences, Kyushu University

TABATA, Toshinori

Faculty of Agriculture, Kyushu University

HIRAMATSU, Kazuaki

Faculty of Agriculture, Kyushu University

HARADA, Masayoshi

Faculty of Agriculture, Kyushu University

他

https://doi.org/10.5109/4103895

出版情報: 九州大学大学院農学研究院紀要. 65 (2)，pp.305-311，2020-09. Faculty of Agriculture， Kyushu University

バージョン :

権利関係 : 


\title{
Flood Hazard Assessment of Residential Areas Inside the Van Coc Lake, Hanoi, in an Emergency Situation
}

\author{
Sai Hong ANH ${ }^{1,2}$, Toshinori TABATA*, Kazuaki HIRAMATSU, \\ Masayoshi HARADA and Le Viet SON $^{2}$
}

\author{
Laboratory of Water Environment Engineering, \\ Division of Bioproduction Environmental Sciences, \\ Department of Agro-environmental Sciences, Faculty of Agriculture, \\ Kyushu University, Fukuoka 819-0395, Japan \\ (Received May 15, 2020 and accepted May 27, 2020)
}

\begin{abstract}
The Van Coc Lake is a regulating reservoir located in the Dan Phuong and Phuc Tho Districts (30 km from the center of the Hanoi Capital). It is usually dry and includes arable land and residential areas. To protect the Hanoi Capital from flood disasters in emergency situations, floodwater is received from the Red River through the Van Coc Gate and the overflow point, and the floodwater drains downstream through the Day Weir. The authors have proposed the effective operating procedure in the emergency situations by optimizing the inflow discharge at the Van Coc Gate and the overflow point, and the outflow discharge at the Day Weir for ensuring the flood mitigation effect of the lake and the safety of the operating system. However, risk-reduction strategies based on a flood hazard assessment for the residential areas located inside the lake have not been adequately resolved. In this study, the inundation situations inside the lake area were identified with a two-dimensional depth-integrated hydrodynamic model in high resolution. The results indicated that the residential areas were highly vulnerable to floods. When the water depth in front of the Day Weir reached $1.0 \mathrm{~m}, 3.0 \mathrm{~m}$, and its peak at $4.9 \mathrm{~m}, 57.13 \%, 85.52 \%$, and $99.76 \%$ of the total residential areas $\left(6.33 \mathrm{~km}^{2}\right)$ were inundated respectively. The highest velocity was primarily focused around the Van Coc Gate, overflow point, and Day Weir with velocities of $0.6-2.0 \mathrm{~m} / \mathrm{s}$.
\end{abstract}

Key words: Flood mapping, flood risk level, two-dimensional depth-averaged model

\section{INTRODUCTION}

Flooding is a common hydrological process and the most frequent natural disaster in the world, and it causes massive damage in terms of loss of lives, resources, and communications (IFRC, 2015; Chowdhuri et al., 2020). Many large areas around the world are affected by flooding more seriously than others. One of these areas is Southeast Asia. This is the most flood-prone region in the world, with substantial residential areas existing on or near the floodplain (Ahamed and Bolten, 2017). In the developing countries of Southeast Asia, including Vietnam, the perception of flooding is nuanced by obvious limitations in research, economy, and policy framework (Nkwunonwo et al., 2020). In fact, flooding is a severe concern in those countries because of its damage scale for inhabitants and built infrastructures (Nur and Shrestha, 2017). In recent decades, the influence of climate change has become more frequent and severe, which has increased flood hazards and enhanced the vulnerability of residential areas on or near the floodplain (Shadmehri et al., 2019; Nur and Shrestha, 2017). Therefore, flood prevention is becoming more critical than ever, and it is a predominant practice in flood haz-

\footnotetext{
1 Laboratory of Water Environment Engineering, Course of Bioproduction Environmental Sciences, Department of Agroenvironmental Sciences, Graduate School of Bioresource and Bioenvironmental Sciences, Kyushu University

Division for Water Resources Planning for the North Region, Institute of Water Resources Planning, 162A-Tran Quang Khai, Hoan Kiem, Hanoi, Vietnam

* Corresponding author. E-mail: ttabata@bpes.kyushu-u.ac.jp
}

ard mitigation. Nations around the world have been striving to protect important residential areas from flooding at all costs with flood control infrastructures (Liao et al., 2019).

As shown in Figure 1, the capital city of Hanoi is located on the Red River Delta in Vietnam. The Red River is an international river and the largest river flowing in northern Vietnam, with three main tributaries: the Da, the Thao, and the Lo. In recent decades, many massive rainfall events have been recorded in the delta, and flooding is a severe problem in the Red River Delta (AHA-JICA, 2015). In 1971, the most extreme flood disaster inflicted in the river basin claimed the lives of 100,000 people and colossal damage to dikes, homes, and possessions. The rapid increase in the water level of the Red River caused the flood disaster (NOAA, 1993), and increased urbanization, economic development, and long-term climate variability have made the river flooding problem more challenging, putting people and property at increased risk. Moreover, flood forecasting of the river discharge is a complex task with multiple sources of uncertainty, especially in an international river basin, with the challenge of transferring knowledge, data, and techniques (Leandro et al., 2019). Consequently, the Vietnamese Government has devoted significant efforts to predicting and mitigating flooding in the Red River (Vietnamese Government, 2011). The Van Coc Lake, shown in Figure 1, is a regulating reservoir located $30 \mathrm{~km}$ from the center of Hanoi. It is usually dry and includes arable land and residential areas. To protect Hanoi from flood disasters, in emergency situations, it receives the floodwater from the Red River through the Van Coc Gate 
and the overflow point, and the floodwater drains downstream through the Day Weir. Anh et al., (2019b) proposed an effective operating procedure for emergency situations that optimizes the inflow discharge at the Van Coc Gate and the overflow point, as well as the outflow discharge at the Day Weir, for ensuring the flood mitigation effect of the lake and the safety of the operating system. Unfortunately, many large residential areas are located inside the Van Coc Lake area and are highly vulnerable during emergency situations. Therefore, identifying vulnerable areas is necessary for the flood risk management of residential areas.

In this study, numerical simulations were performed to assess the influence of floodwater on the residential areas inside the Van Coc Lake area when the effective operating procedure for emergency situations, which was obtained from the preceding study (Anh et al., 2019b), is conducted to protect Hanoi. A two-dimensional depth-integrated hydrodynamic model was constructed to simulate the inundation of residential areas around Van Coc Lake. The influence of floodwater on the residential areas inside the Van Coc Lake area was investigated by the model and the boundary conditions of the effective operating procedure in emergency situations.

\section{MATERIALS AND METHODS}

\section{Study area and boundary conditions}

Figure 1 indicates the location of the Van Coc Lake.
The research area covered an area of $30.8 \mathrm{~km}^{2}$ and comprised 12,333 grid cells with a resolution of $50 \mathrm{~m}$. A twodimensional hydrodynamic model was utilized for inundation simulations in the Van Coc Lake. The model was validated in previous research (Anh et al., 2019a, 2019b). Topographic data were surveyed by the Institute of Water Resources Planning under the Ministry of Agriculture and Rural Development, Vietnam, in 2011 and 2013. The natural neighbor technique in ESRI's ArcGIS software was utilized for interpolating topographic surfaces from the available points to calculate the elevation for each cell.

The optimized inflow discharges at the Van Coc Gate and the overflow point to protect Hanoi in emergency situations, which were obtained by the scenario analyses in the preceding study (Anh et al., 2019b), were used as the input boundary condition. The outflow discharge at the Day Weir was also recommended in the preceding study and used here as the outflow boundary condition. Figure 2 depicts the maximum discharges at the Van Coc Gate, overflow point, and Day Weir, which were $1407 \mathrm{~m}^{3} / \mathrm{s}, 1224 \mathrm{~m}^{3} / \mathrm{s}$, and $2368 \mathrm{~m}^{3} / \mathrm{s}$, respectively, in the effective operating procedure in the emergency situations.

\section{Hydrodynamic model}

Recently two-dimensional and three-dimensional hydrodynamic models are utilized widely to simulate water flow dynamics (Abedini and Ghiassi, 2010; Wu and Lin, 2015; Bellos and Tsakiris, 2015, Hu and Kot, 1997).

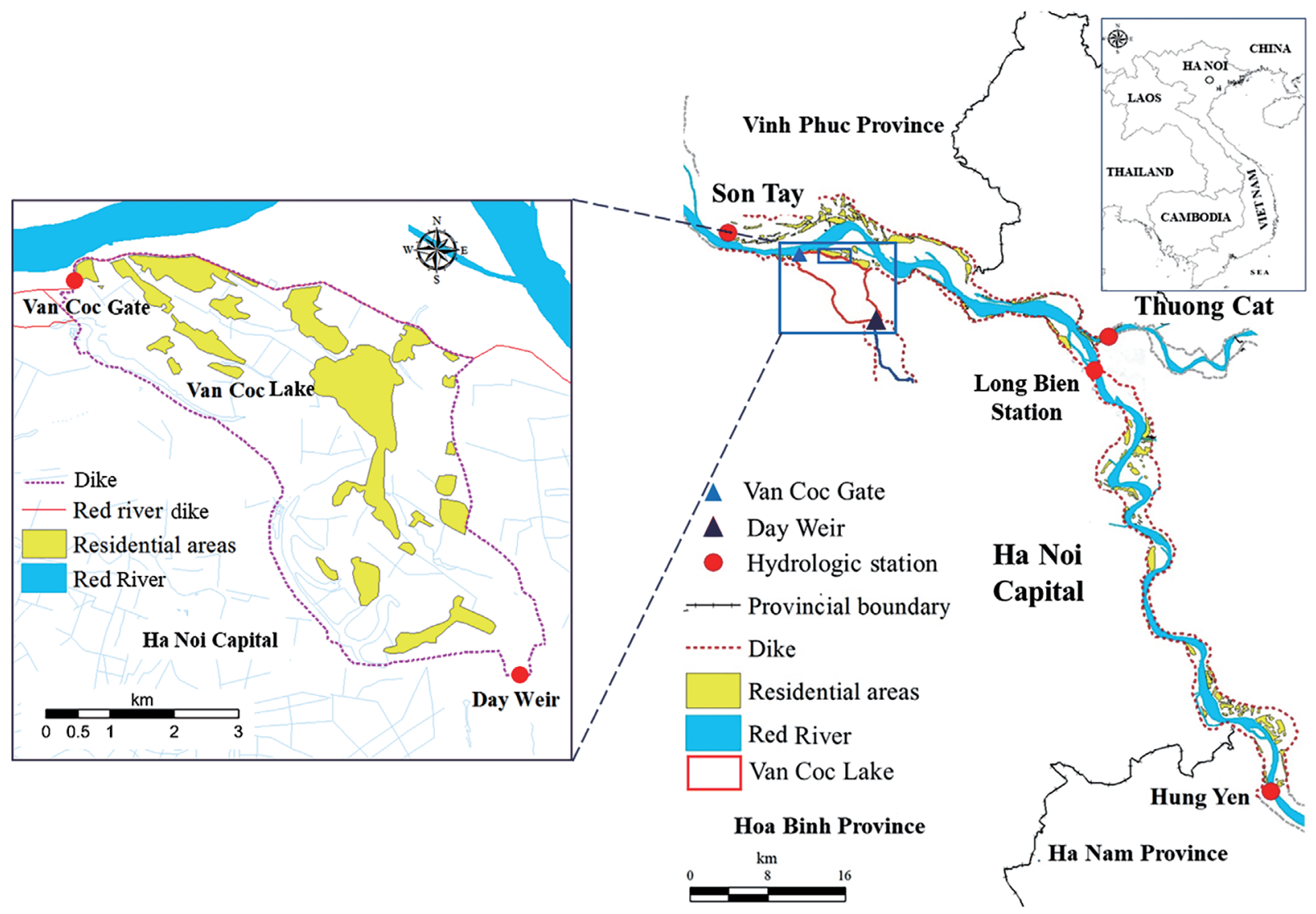

Fig. 1. Location of the Van Coc Lake. 


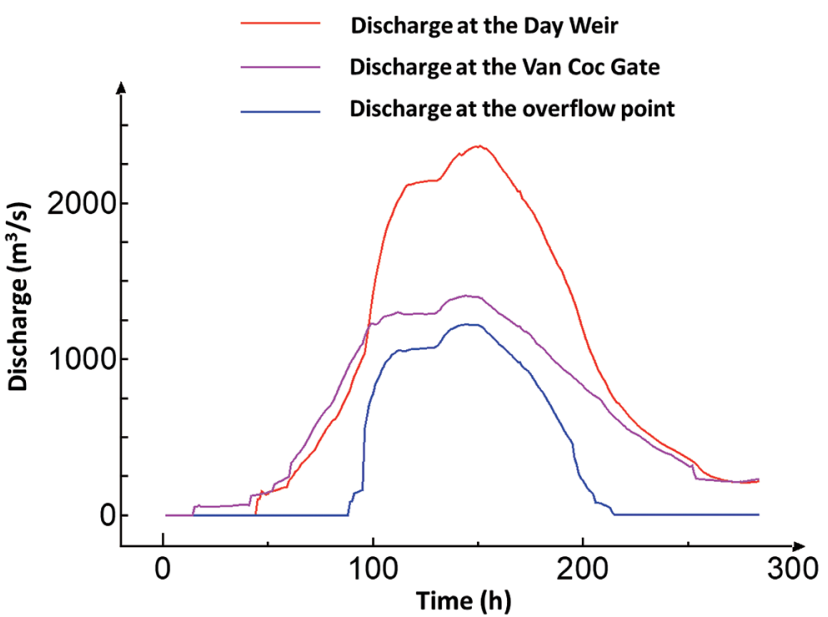

Fig. 2. Inflow discharges at the Van Coc Gate, the overflow point, and the outflow discharge of the Day Weir in the effective operating procedure in emergency situations to protect the Hanoi Capital.

In this study, the research area is a floodplain and focuses on the behavior of floodwater, wherein the horizontal velocities are far greater than the vertical velocities. Therefore, we applied a two-dimensional depthintegrated model to simulate the behavior of floodwater in the area. The shallow water equations used in this study are as follows:

Continuity equation:

$$
\frac{\partial \eta}{\partial t}+\frac{\partial}{\partial x}\{U(h+\eta)\}+\frac{\partial}{\partial y}\{V(h+\eta)\}=0
$$

Momentum equations in the $x$ - and $y$-directions:

$$
\begin{aligned}
& \frac{\partial U}{\partial t}+U \frac{\partial U}{\partial x}+V \frac{\partial U}{\partial y}=f V-g \frac{\partial \eta}{\partial x}+v_{h}\left(\frac{\partial^{2} U}{\partial x^{2}}+\frac{\partial^{2} U}{\partial^{2} y}\right) \\
& -\frac{g n^{2} U \sqrt{U^{2}+V^{2}}}{(h+\eta)^{4 / 3}} \\
& \frac{\partial V}{\partial t}+U \frac{\partial V}{\partial x}+V \frac{\partial V}{\partial y}=-f U-g \frac{\partial \eta}{\partial y}+v_{h}\left(\frac{\partial^{2} V}{\partial x^{2}}+\frac{\partial^{2} V}{\partial^{2} y}\right) \\
& -\frac{g n^{2} V \sqrt{U^{2}+V^{2}}}{(h+\eta)^{4 / 3}}
\end{aligned}
$$

where $U$ and $V$ are the depth-averaged horizontal velocity components in the $x$ and $y$ directions $(\mathrm{m} / \mathrm{s}), \eta$ is the water level (m), $t$ is time (s), $h$ is the water depth (m), $f$ is the Coriolis force $(1 / \mathrm{s}), g$ is the gravitational acceleration $\left(\mathrm{m} / \mathrm{s}^{2}\right), n$ is Manning's coefficient of roughness $\left(\mathrm{s} / \mathrm{m}^{1 / 3}\right)$, and $v_{h}$ is the coefficient of eddy viscosity $\left(\mathrm{m}^{2} / \mathrm{s}\right)$. The coefficient of the eddy viscosity $v_{h}$ was calculated using the Smagorinsky model (1963) as follows:

$$
\begin{aligned}
& v_{h}=\frac{1}{2} S_{m} A_{G}\left\{\left(\frac{\partial U}{\partial x}\right)^{2}+\frac{1}{2}\left(\frac{\partial V}{\partial x}+\frac{\partial U}{\partial y}\right)\right. \\
& \left.+\left(\frac{\partial V}{\partial y}\right)^{2}\right\}^{1 / 2}
\end{aligned}
$$

where $S_{m}$ is the Smagorinsky coefficient, and $A_{G}$ is the area of each mesh point $\left(\mathrm{m}^{2}\right)$.
The basic parameters are defined as follows: the temporal discretization $\Delta t=2.0 \mathrm{~s}$; the special discretization $\Delta x=\Delta y=50 \mathrm{~m} ; S_{m}=0.2 ; A_{G}=\Delta x \Delta y=2500 \mathrm{~m}^{2} ; f=$ $5.24 * 10^{-5} 1 / \mathrm{s}^{-1}$; and $g=9.8 \mathrm{~m} / \mathrm{s}^{2}$. Manning's coefficient of roughness $n$ for each grid element was set to be $n=$ $0.025 \mathrm{~s} / \mathrm{m}^{1 / 3}-0.172 \mathrm{~s} / \mathrm{m}^{1 / 3}$ depending on the vegetation, obstructions, and residential areas. The leapfrog finite difference method was applied to calculate the governing equations on the staggered mesh system. The model was run with a time step of $\Delta t=2.0 \mathrm{~s}$, in which the water level and velocity were calculated alternately. A wetting-and-drying scheme of Uchiyama (2004) was used to identify the wet and dry areas at each time step. Besides, Figure 2 shows the simulation period from $16^{\text {th }}$ August to $27^{\text {th }}$ August, 1971 that is the 11-day data of the catastrophic flood in this year. The main initial boundary conditions were set up as follows: the water depth for all cells is $0.2 \mathrm{~m}$, the depth-averaged horizontal velocity components $U$ and $V$ are zero.

\section{RESULTS AND DISCUSSION}

\section{Inundated areas}

Table 1 shows the percentage of the inundated residential area when the water depth in front of the Day Weir reached $1.0 \mathrm{~m}, 2.0 \mathrm{~m}, 3.0 \mathrm{~m}, 4.0 \mathrm{~m}$, and $4.9 \mathrm{~m}$ in the effective operating procedure in the emergency situations. The Day Weir was built 70 years ago and has deteriorated, and overload must be avoided. Therefore, it was concluded that a weir height of $4.9 \mathrm{~m}$ was equivalent to critical water depth for its safety in the preceding study (Anh et al., 2019b). Table 1 indicates five inundation depth levels used to summarize the percentage of the inundated residential areas. Most of the residential areas inside the Van Coc Lake area were inundated with $57.13 \% \quad\left(3.62 \mathrm{~km}^{2}\right), \quad 70.21 \% \quad\left(4.44 \mathrm{~km}^{2}\right), \quad 85.52 \%$ $\left(5.41 \mathrm{~km}^{2}\right), 98.45 \%\left(6.23 \mathrm{~km}^{2}\right)$, and $99.76 \%\left(6.31 \mathrm{~km}^{2}\right)$ when the water depth in front of the Day Weir reached $1.0 \mathrm{~m}, 2.0 \mathrm{~m}, 3.0 \mathrm{~m}, 4.0 \mathrm{~m}$, and $4.9 \mathrm{~m}$, respectively. The most dangerously inundated residential areas were at Inundation Depth Level 5 from $3.0 \mathrm{~m}$ and above. The values increased significantly from $1.35 \% \quad\left(0.09 \mathrm{~km}^{2}\right)$ when the water depth reached $1.0 \mathrm{~m}$ at the Day Weir to $5.51 \%\left(0.34 \mathrm{~km}^{2}\right), 17.41 \%\left(1.1 \mathrm{~km}^{2}\right), 44.9 \%\left(2.84 \mathrm{~km}^{2}\right)$ and $64.38 \%\left(4.08 \mathrm{~km}^{2}\right)$, respectively when the water depth reached $2.0 \mathrm{~m}, 3.0 \mathrm{~m}, 4.0 \mathrm{~m}$ and $4.9 \mathrm{~m}$ at the Day Weir. This indicates that flood risk levels for the residential areas increased rapidly, and they were dangerous when the Van Coc Gate, Day Weir, and the overflow point were operated. When the water depth reached $2.0 \mathrm{~m}$ at the Day Weir, there was a significant increase in the percentage of inundated residential areas for the Inundation Depth Levels 3, 4, and 5- 28.88\% $\left(1.83 \mathrm{~km}^{2}\right), \quad 13.45 \% \quad\left(0.85 \mathrm{~km}^{2}\right)$ and $5.51 \% \quad\left(0.34 \mathrm{~km}^{2}\right)$ respectively. However, the percentage of Inundation Depth Levels 1 and 2 decreased in comparison when the water depth reached $1.0 \mathrm{~m}$ at the Day Weir from 15.99\% $\left(1.01 \mathrm{~km}^{2}\right)$ to $9.8 \%\left(0.62 \mathrm{~km}^{2}\right)$ and from $15.99 \%$ $\left(1.01 \mathrm{~km}^{2}\right)$ to $12.57 \%\left(0.8 \mathrm{~km}^{2}\right)$, respectively. When the water depth reached $3.0 \mathrm{~m}$ at the Day Weir, $85.52 \%$ 
$\left(5.41 \mathrm{~km}^{2}\right)$ of residential areas were flooded, with $6.27 \%$ $\left(0.4 \mathrm{~km}^{2}\right)$ of the residential areas inundated from $0.2 \mathrm{~m}$ to $0.5 \mathrm{~m}, 10.55 \%\left(0.67 \mathrm{~km}^{2}\right)$ from $0.5 \mathrm{~m}$ to $1.0 \mathrm{~m}, 24.16 \%$ $\left(1.53 \mathrm{~km}^{2}\right)$ from $1.0 \mathrm{~m}$ to $2.0 \mathrm{~m}, 27.13 \%\left(1.71 \mathrm{~km}^{2}\right)$ from $2.0 \mathrm{~m}$ to $3.0 \mathrm{~m}$, and $17.41 \%\left(1.1 \mathrm{~km}^{2}\right)$ at $3.0 \mathrm{~m}$ or more. The results showed that the residential areas were mainly inundated to a depth of $1.0 \mathrm{~m}$ to $3.0 \mathrm{~m}$ when water depth reached $3.0 \mathrm{~m}$ at the Day Weir. In addition, the simulated results indicated that, when the water depth touched $4.0 \mathrm{~m}$ at the Day Weir, the residential areas were mainly inundated, with $44.9 \%\left(2.84 \mathrm{~km}^{2}\right)$ at a depth of more than $3.0 \mathrm{~m}$. More seriously, when the water depth in front of the Day Weir reached $4.9 \mathrm{~m}$, $64.38 \%\left(4.08 \mathrm{~km}^{2}\right)$ of the residential areas were underwater at $3.0 \mathrm{~m}$ or more. Further, a huge residential area was inundated at Inundation Depth Levels 3 and $4-12.89 \%\left(0.82 \mathrm{~km}^{2}\right)$ and $21.06 \%\left(1.32 \mathrm{~km}^{2}\right)$, respectively. These results could be explained by the rapid increase of the water depth in front of the Day Weir, and these led to a huge damage in terms of the loss of lives and property.

\section{Flood risk mapping}

Figure 3 shows the flood risk mapping and the most vulnerable residential areas (R1, R2, R3, R4, R5, and R6) of the inundated residential area when the water depth in front of the Day Weir reached $1.0 \mathrm{~m}, 2.0 \mathrm{~m}, 3.0 \mathrm{~m}$, $4.0 \mathrm{~m}$ and $4.9 \mathrm{~m}$ in the effective operating procedure in the emergency situation. From the simulated results, the residential areas most vulnerable to flooding were identified. R3 was the most heavily affected by floodwater and was rapidly covered by floodwater from $1.0 \mathrm{~m}$ to $3.0 \mathrm{~m}$ even when the water depth in front of the Day Weir reached $1.0 \mathrm{~m}$. When the water depth in front of the Day Weir reached $2.0 \mathrm{~m}, 3.0 \mathrm{~m}, 4.0 \mathrm{~m}$, and $4.9 \mathrm{~m}$, the $\mathrm{R} 3$ area was always the most dangerous residential area. R3, located on the main flood flow, has a low elevation, which heavily influenced the floodwater.

R4, R5, and R6 are located in the south of the Van Coc Lake area and the downstream end of the lake. Therefore, the elevation is lower than for the upstream locations. This causes high flood risk vulnerability levels for R4, R5, and R6. When the water depth touched $2 \mathrm{~m}$ at the Day Weir, some residential areas were inundated from $2.0 \mathrm{~m}$ to $3.0 \mathrm{~m}$, but most of them were inundated from $1.0 \mathrm{~m}$ to $2.0 \mathrm{~m}$ in $\mathrm{R} 1$ and $\mathrm{R} 2$. However, many residential areas were flooded by more than $3.0 \mathrm{~m}$, but mainly from 1.0 to $3.0 \mathrm{~m}$ in R4, R5, and R6. All the vulnerable residential areas faced a more significant challenge in flooding when the water reached a depth of $3 \mathrm{~m}$ at the Day Weir. Approximately half the residential areas located in R4, R5, and R6 were inundated from 2.0 $\mathrm{m}$ to $3.0 \mathrm{~m}$ and above. When the water depth reached $4.0 \mathrm{~m}$ and $4.9 \mathrm{~m}$ at the Day Weir, most of the residential areas were underwater to depths of $3.0 \mathrm{~m}$ and above. Obviously, the residential areas located in the Van Coc Lake area were rapidly covered by floodwater - approximately $99.76 \%\left(6.29 \mathrm{~km}^{2}\right)$ when the Van Coc Gate, overflow point, and Day Weir operated in the effective operating procedure in the emergency situations to protect Hanoi.

\section{Highest velocity}

Figure 4 shows the highest flow velocity at each cell in the case of operating the Van Coc Gate, overflow point, and Day Weir in the effective operating procedure in emergency situations, as well as the land use map in the targeted area. In the areas located around the Van Coc Gate, the highest flow velocities were mainly concentrated near the Van Coc Gate, with values ranging from 0.8 to $2.0 \mathrm{~m} / \mathrm{s}$. The flow velocities were also high near the overflow point, with values from $0.4 \mathrm{~m} / \mathrm{s}$ to $0.8 \mathrm{~m} / \mathrm{s}$. The remaining areas located in the south-west of the Van Coc Lake had smaller velocities, from 0.2 to $0.4 \mathrm{~m} / \mathrm{s}$. The high velocity was recorded around the Day Weir, from 0.6 to $2.0 \mathrm{~m} / \mathrm{s}$. However, there were many residential areas located in the V1 area, which caused a small flow velocity, fluctuating between 0.1 and $0.3 \mathrm{~m} / \mathrm{s}$. Clearly, the flow velocities around the residential areas were not high, and the highest-velocity areas were primarily concentrated around the Van Coc Gate, overflow point, and Day Weir.

\section{CONCLUSION}

This study comprehensively assessed the flood hazard for the residential areas located inside the Van Coc Lake area when using the effective operating procedure of the Van Coc Gate, overflow point, and Day Weir in an

Table 1. Percentages of inundated residential areas when the water depth in front of the Day Weir reached $1.0 \mathrm{~m}, 2.0 \mathrm{~m}$, $3.0 \mathrm{~m}, 4.0 \mathrm{~m}$, and $4.9 \mathrm{~m}$ in the effective operating procedure in the emergency situation. The total residential area inside the Van Coc Lake was $6.33 \mathrm{~km}^{2}$

\begin{tabular}{|c|c|c|c|c|c|c|c|c|c|c|}
\hline Water depth levels & \multicolumn{2}{|c|}{$1.0 \mathrm{~m}$} & \multicolumn{2}{|c|}{$2.0 \mathrm{~m}$} & \multicolumn{2}{|c|}{$3.0 \mathrm{~m}$} & \multicolumn{2}{|c|}{$4.0 \mathrm{~m}$} & \multicolumn{2}{|c|}{$4.9 \mathrm{~m}$} \\
\hline Total inundated residential areas & 57.13 & 3.62 & 70.21 & 4.44 & 85.52 & 5.41 & 98.45 & 6.23 & 99.76 & 6.31 \\
\hline Water depth level 1: $0.2 \mathrm{~m}-0.5 \mathrm{~m}$ & 15.95 & 1.01 & 9.8 & 0.62 & 6.27 & 0.40 & 2.30 & 0.15 & 0.20 & 0.01 \\
\hline Water depth level 2: $0.5 \mathrm{~m}-1.0 \mathrm{~m}$ & 15.99 & 1.01 & 12.57 & 0.8 & 10.55 & 0.67 & 7.38 & 0.46 & 1.23 & 0.08 \\
\hline Water depth level $4: 2.0 \mathrm{~m}-3.0 \mathrm{~m}$ & 6.62 & 0.42 & 13.45 & 0.85 & 27.13 & 1.71 & 23.48 & 1.49 & 21.06 & 1.32 \\
\hline Water depth level 5: $3.0 \mathrm{~m}<$ & 1.35 & 0.09 & 5.51 & 0.34 & 17.41 & 1.10 & 44.9 & 2.84 & 64.38 & 4.08 \\
\hline
\end{tabular}



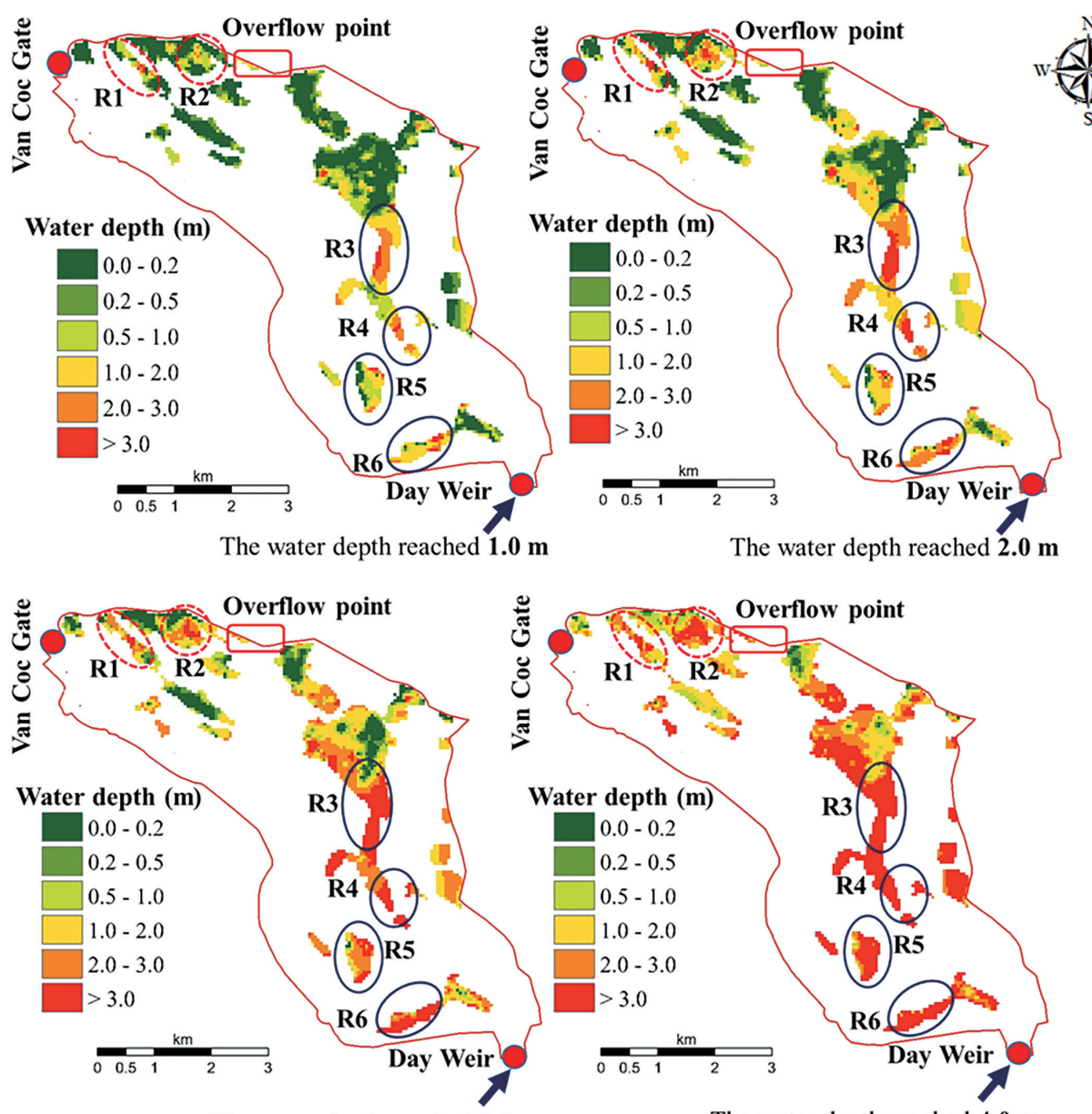

The water depth reached $3.0 \mathrm{~m}$

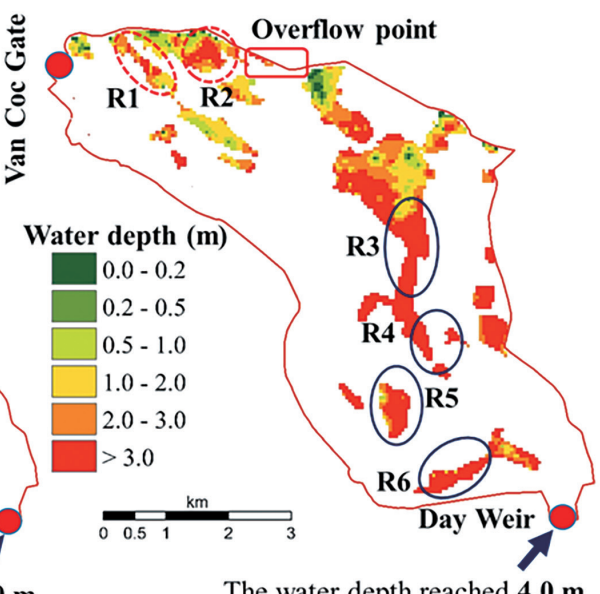

Overflow point

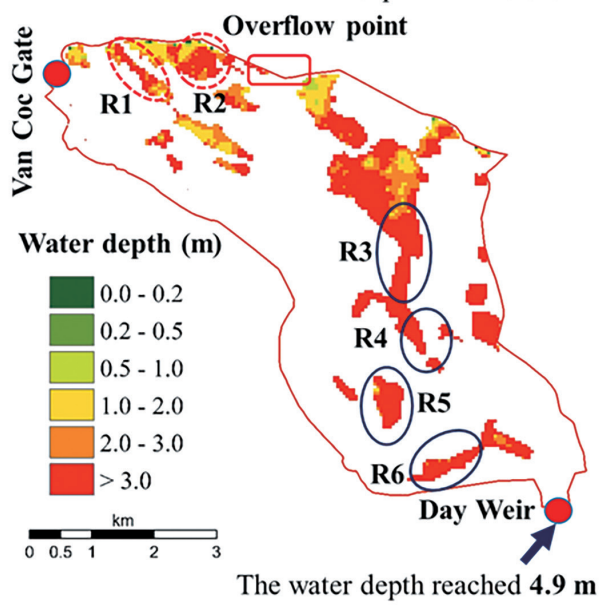

The water depth reached $4.0 \mathrm{~m}$

Fig. 3. Flood risk mapping and the most-vulnerable residential areas (R1, R2, R3, R4, R5, and R6) of the inundated residential area when the water depth in front of the Day Weir reached $1.0 \mathrm{~m}, 2.0 \mathrm{~m}$, $3.0 \mathrm{~m}, 4.0 \mathrm{~m}$ and $4.9 \mathrm{~m}$ in the effective operating procedure in the emergency situation.

emergency situation to protect Hanoi from flooding. A two-dimensional depth-integrated hydrodynamic model was constructed to simulate inundation in Van Coc Lake. A research area comprising grid cells with a 50-m resolution was utilized. A wetting-and-drying scheme was used to identify the wet and dry areas at each time step.

To identify flood risk levels in the residential areas, the optimized discharges at the Van Coc Gate, overflow point, and Day Weir for protecting Hanoi in an emergency situation, which were obtained by the scenario analyses in a preceding study (Anh et al., 2019b), were used as the input and output boundary conditions. The results indicated that most of the residential areas were inundated, with $57.13 \%\left(3.62 \mathrm{~km}^{2}\right), 70.21 \%\left(4.43 \mathrm{~km}^{2}\right)$, $85.52 \% \quad\left(5.40 \mathrm{~km}^{2}\right), \quad 98.45 \% \quad\left(6.22 \mathrm{~km}^{2}\right)$ and $99.76 \%$ $\left(6.29 \mathrm{~km}^{2}\right)$ when the water depths in front of the Day Weir reached 1.0, 2.0, 3.0, 4.0, and $4.9 \mathrm{~m}$, respectively, and they were rapidly covered by floodwater. In addition, the highest-velocity areas were primarily concentrated around the Van Coc Gate, overflow point, and Day 

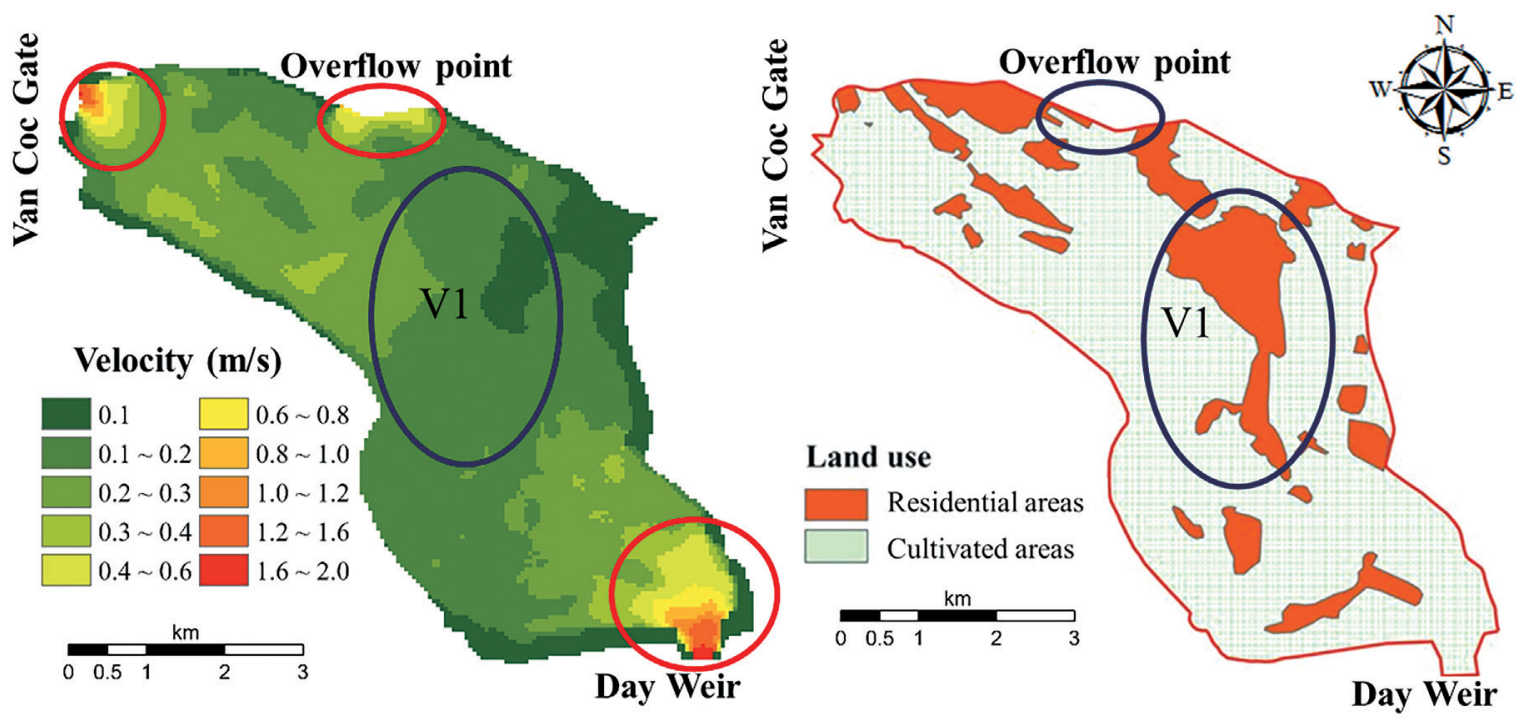

Fig. 4. Highest velocity distribution and the land use map.

Weir, with velocities between 1.0 and $2.0 \mathrm{~m} / \mathrm{s}$. The remaining areas had smaller velocities of between 0.2 and $0.4 \mathrm{~m} / \mathrm{s}$. It is clear that the Van Coc Lake area is hazardous in emergency situations, during which Hanoi must be protected from flooding. Therefore, an immigration plan is needed for the design of risk-reduction strategies and the overall development planning of Hanoi.

\section{AUTHOR CONTRIBUTIONS}

S. H. ANH, T. TABATA, and K. HIRAMATSU designed the study and conducted the field observations. L. V. SON contributed to the field observations. S. H. ANH wrote the draft of the manuscript. T. TABATA, K. HIRAMATSU, M. HARADA and L. V. SON revised the manuscripts. All authors approved the final version of the manuscript and agree to be accountable for all aspects of the work, ensuring that questions related to the accuracy or integrity of any part of the work are appropriately investigated and resolved.

\section{ACKNOWLEDGMENTS}

The authors appreciate the funding support of JSPS KAKENHI Grant Numbers JP18H03968 and JP17K15347.

\section{REFERENCES}

Abedini, A. A. and R. Ghiassi 2010 A Three- Dimensional Finite Volume Model for Shallow Water Flow Simulation. Australian Journal of Basic and Applied Sciences, 4, pp. 3208-3215

AHA (ASEAN Coordinating Centre for Humanitarian Assistance on Disaster Management) \& JICA (Japan International Cooperation Agency) 2015 Natural Disaster Risk Assessment and Area Business Continuity Plan Formulation for Industrial Agglomerated Areas in the ASEAN Region, 2013 to 2015. Country Report-Vietnam

Ahamed, A. and J. D. Bolten 2017 A MODIS- based automated flood monitoring system for Southeast Asia, International
Journal of Applied Earth Observation and Geoinformation., 61(5), pp. 104-117. DOI: 10.1016/j.jag.2017.05.006

Anh, S. H., T. Tabata, K. Hiramatsu, M. Harada and L.V Son $2019 a$ Assessment of Floodwater Behavior in Van Coc Lake, Hanoi in Event of Emergency Situation, Japan Agricultural Research Quarterly, 53(3), pp.181-190. DOI: 10.6090/jarq.53.181

Anh, S. H., T. Tabata, K. Hiramatsu, M. Harada and L. N. Chung 2019b An optimal scenario for the emergency solution to protect the Hanoi Capital from flood disaster of the Red River by using the Van Coc Lake, Journal of Flood Risk Management. (Submitted)

Bellos, V. and G. Tsakiris 2015 Comparing Various Methods of Building Representation for 2D Flood Modelling In Built- Up Areas. Water Resources Management, 29, pp. 379-397

Chowdhuri, I., S. C. Pal and R. Chakrabortty 2020 Flood susceptibility mapping by ensemble evidential belief function and binomial logistic regression model on river basin of eastern India, Advances in Space Research, 65(5), pp. 1466-1489. DOI: 10.1016/j.asr.2019.12.003

Hu, S. and S. C. Kot 1997 Numerical Model of Tides in Pearl River Estuary with Moving Boundary. Journal of Hydraulic Engineering, 123: 9404

IFRC (International Federation of Red Cross and Red Crescent Societies) 2015 World Disaster Report - Focus on local actors, the key to humanitarian effectiveness

Leandro, J., A. Gander, M. N. A Beg, P. Bhola, I. Konnerth, W. Willems and R. Carvalho 2019 Forecasting upper and lower uncertainty bands of river flood discharges with high predictive skill, Journal of Hydrology, 576(6), pp. 749-763. DOI 10.1016/j.jhydrol.2019.06.052

Liao, K. H., J. K. H. Chan and Y. L. Huang 2019 Environmental justice and flood prevention: The moral cost of floodwater redistribution, Landscape Urban Planning, 189, pp. 36-45. DOI: 10.1016/j.landurbplan.2019.04.012

Nkwunonwo, U. C., M. Whitworth and B. Baily 2020 A review of the current status of flood modeling for urban flood risk management in the developing countries, Scientific African 00269. DOI: $10.1016 /$ j.sciaf.2020.e00269

NOAA (National Oceanic and Atmospheric Administration) National Weather Service Public 1993 NOAA's Top Global Weather, Water, and Climate Events of the 20. US National Oceanic and Atmospheric Administration

Nur, I. and K. K. Shrestha 2017 An Integrative Perspective on Community Vulnerability to Flooding in Cities of Developing Countries, Procedia Engineering, 198(9), pp. 958-967. DOI: 10.1016/j.proeng.2017.07.141

Shadmehri, A., G. Humberto and H. Nouri 2019 River basin- 
scale flood hazard assessment using a Modi fi ed multi- criteria decision analysis approach: A case study, Journal of Hydrology, 574(3): 660-671. DOI: 10.1016/j.jhydrol.2019.04.072

Smagorinsky, J. 1963 General circulation experiments with the primitive equations. Monthly Weather Review, 91, pp. 99-164

Uchiyama, Y. 2004 Modeling wetting and drying scheme based on an extended logarithmic law for a three- dimensional sigmacoordinate coastal ocean model. Rep. Port Airpt. Res. Inst., 43, pp. $3-21$
Vietnamese Government 2011 04/2011/ND- CP: Abolish the use of flooding diversion areas and flooding diversion system of Day river, Vietnam. http://www.tongcucthuyloi.gov.vn/He- thongvan- ban/Van- ban- phap- luat/docid/566/nghi- dinh- 042011- nd- cp- thuc- hien- bai- bo- viec- su- d. (In Vietnamese). Accessed 15 February 2020

Wu, W. and Q. Lin 2015 Advances in water resources A 3- D implicit finite- volume model of shallow water flows. Adv. Water Resources., 83, pp. 263-276 
